\title{
ANALYSIS OF THE UTILIZATION OF THE SOCIAL CENTER FOR ORANGUTAN PROTECTION (COP) IN KALIMANTAN IN ORANGUTAN SAVING EFFORTS
}

\author{
ANALISIS PEMANFAATAN JARINGAN SOSIAL CENTRE FOR \\ ORANGUTAN PROTECTION (COP) DI KALIMANTAN DALAM \\ UPAYA PENYELAMATAN ORANGUTAN
}

\author{
Octalina Hardiyanti ${ }^{1}$, Agustin Nurmanina ${ }^{2}$ \\ Universitas Mulawarman, Indonesia \\ Email Correspondence: orangutaa@gmail.com
}

\begin{abstract}
:
Utilization of the Center for Orangutan Protection (COP) 2 social network in Kalimantan. With the limited number of human resources compared to the wide scope of work in all of Kalimantan, COP makes use of its social networks to meet the needs and the functioning of the organization. In investigative activities, COP has effectively used weak ties to obtain information on the whereabouts of orangutans and the destruction of their habitat. The policies in this activity are also dominated by central actors through their power networks which result in network stability. In contrast to the use of social networks for educational activities, local actors are more dominant in making program policies and work patterns. In the alternation between actors from time to time, there are differences in assumptions and work patterns of the actors in charge, resulting in differences in utilization results and potential network damage. COP can utilize its social network in fulfilling its function as an NGO campaigning for the protection and rescue of orangutans, but on the other hand, COP's bonding social network only connects this NGO with similar organizations, limited to handling cases of orangutans and their habitat. Supporting nature conservation, such as economic, social, and cultural, as part of the needs of the community around the ring habitat is not fulfilled.
\end{abstract}

Keywords: NGO's, Organizations, Social Capital, Social Networks, Weak Bonds

\section{ABSTRAK:}

Pemanfaatan jaringan sosial Centre for Orangutan Protection (COP)2 di Kalimantan. Dengan keterbatasan jumlah SDM dibanding luasnya cakupan kerja di seluruh Kalimantan, COP memanfaatkan jaringan sosialnya untuk memenuhi kebutuhan dan berjalannya fungsi organisasi. Dalam kegiatan investigasi COP efektif menggunakan ikatan lemah untuk memperoleh informasi keberadaan orangutan dan perusakan habitatnya. Kebijakan dalam aktivitas ini pun didominasi aktor pusat melalui jaringan powernya yang menghasilkan stabilitas jaringan. Berbeda dengan pemanfaatan jaringan sosial untuk kegiatan edukasi, aktor lokal lebih dominan mengambil kebijakan program dan pola kerja. Dalam pergantian antar aktor pada masa ke masa terdapat perbedaan asumsi dan pola kerja aktor-aktor yang bertugas sehingga menimbulkan perbedaan hasil pemanfaatan hingga potensi terjadinya kerusakan jaringan. COP mampu memanfaatkan jaringan sosialnya dalam memenuhi fungsinya sebagai LSM yang mengkampanyekan perlindungan dan penyelamatan orangutan, namun sisi lainnya jaringan sosial COP yang bersifat bonding (tertutup) hanya menghubungkan LSM ini dengan organisasi sejenis terbatas pada penanganan kasus orangutan dan habitatnya. Pendukung konservasi alam seperti ekonomi, sosial dan budaya sebagai bagian dari kebutuhan masyarakat di sekitar ring habitat tak terpenuhi.

Kata Kunci: Ikatan Lemah, Jaringan Sosial, Kapital Sosial, LSM, Organisasi

\section{Article Info}

Received

Accepted

Published

DOI
January 2020

January 2020

January 2020

https://doi.org/10.30872/psd.v1i1.14

Copyright and License

Authors retain copyright and grant the journal right of first publication with the work simultaneously licensed under a Creative Commons Attribution 4.0 International License that allows others to share the work with an acknowledgment of the work's authorship and initial publication in this journal. 


\section{PENDAHULUAN}

Pulau Kalimantan sebagai paru-paru dunia karena luas hutannya, yaitu sekitar 40,8 juta hektar. Namun, laju deforestasi mengancam hal ini. Menurut Departemen Kehutanan, angka deforestasi di Kalimantan pada 2000 sampai. dengan 2005 mencapai sekitar 1,23 juta ha. Perusakan lapisan atas hutan dengan cara merubah penggunaan lahan secara permanen atau deforestasi di Indonesia selain disebabkan oleh industri kayu yang semakin mempersempit hutan alami, juga pengalihan fungsi (konversi) hutan untuk perkebunan kelapa sawit. 3

Berkurangnya luasan dan kualitas hutan dalam beberapa dekade terakhir berpengaruh buruk terhadap dinamika tutupan hutan maupun kawasan hutan di Indonesia. Peningkatan potensi ekonomi yang tinggi justru banyak mengorbankan hutan yang memiliki kekayaan aset biodiversitas dan jasa lingkungan tak terhitung, termasuk menjadi ancaman serius bagi berbagai jenis satwa langka di Kalimantan, antara lain orangutan, bekantan, beruang madu dan berbagai jenis owa. Khususnya orangutan, pada beberapa tahun terakhir ini kecepatan penurunan populasi orangutan terus meningkat akibat hilangnya hutan dataran rendah. Data tahun 2004 menunjukkan bahwa di perkirakan jumlah orangutan Kalimantan hanya 58.575 ekor. Prediksi para ahli, jika kondisi ini tidak membaik, maka dalam 10 tahun terakhir kita akan kehilangan hampir 50\% dari jumlah populasi yang ada saat ini.

Centre for Orangutan Protection (COP) dibentuk pada tahun 2007 sebagai respon darurat untuk menghentikan pembabatan hutan di kantong-kantong habitat orangutan yang tersisa, bekerja bahu membahu dengan masyarakat untuk menghentikan dan mencegah pembabatan hutan di Kalimantan. Dalam perkembangannya, COP juga menolong orangutan yang terkurung di dalam kandang-kandang yang buruk kondisinya di kebun binatang serta membantu aparat penegak hukum untuk memberantas perburuan dan perdagangan orangutan.5 Diawali dengan tiga orang pendiri COP dan saat ini beranggotakan 14 orang staf yang terbagi untuk beberapa pusat kegiatan di Kalimantan, Sumatera, Jawa dan Bali. Dengan keterbatasan staf ini, COP bekerja mengandalkan jaringan- jaringannya dalam melakukan kegiatannya, baik internal (maupun eksternal.

Jaringan internal, terdapat Orangufriends, sebuah komunitas relawan yang dibentuk untuk membantu tugas-tugas staf. Orangufriends membantu COP dengan menggalang dana, agen penyebaran informasi mengenai orangutan serta sebagai tenaga sukarela untuk menjalankan kegiatan. Jaringan eksternal, COP bekerjasama dengan pihak lain. Mereka melakukan animal rescue atau penyelamatan orangutan yang menjadi korban konflik dengan manusia bekerjasama dengan BOSF, survey keanekaragaman hayati dengan Jakarta Animal Aid Network (JAAN) di hutan Tumbang Koling, salah satu habitat penting di Kalimantan Tengah serta aksi penggalangan dana bersama grup-grup musik Shaggy Dog, Miskin Porno dan Navicula.

Di Kalimantan Timur, COP bekerjasama dengan Balai Konservasi Sumber Daya Alam (BKSDA) Kalimantan Timur dalam melindungi orangutan, khususnya sub species Pongo Pygmaeus Morio. COP juga melakukan aktivitas bersama organisasi lain seperti aksi penggalangan dana untuk konservasi orangutan oleh beberapa grup musik lokal di Samarinda dan Tenggarong serta Badan Eksekutif Mahasiswa (BEM) Universitas Mulawarman (Unmul) serta kegiatan bersama komunitas-komunitas berbasis kemahasiswaan dan lingkungan hidup seperti Koalisi Pemuda Hijau Indonesia Kalimantan Timur (KOPHI Kaltim), Himpunan Mahasiswa Teknik Lingkungan Universitas Mulawarman (Himateli Unmul) dan Ikatan Mahasiswa Pencinta Alam Universitas Mulawarman (Imapa Unmul).COP juga mempunyai jaringan di kantong-kantong habitat berupa kontak lokal yang akan memberikan informasi mengenai kejahatan terhadap orangutan dan habitatnya.Jaringan sosial COP terbentuk atas hubungan sosial yang terjadi antara aktor yang terlibat didalamnya. Aktor-aktor tersebut (termasuk didalamnya staf COP, relawan, lembaga pemerintahan, lembaga konservasi, lembaga pendidikan, media massa, komunitas lingkungan hidup, kelompok pecinta alam, organisasi mahasiswa, dan masyarakat luas, donatur) mempunyai fungsi dan kebutuhan masing-masing yang berbeda tiap individu maupun kelompok dalam keikutsertaannya.

Agusyanto (Agusyanto,Hal .8-13) menyatakan bahwa terdapat komponen-komponen dan prinsip-prinsip yang mendasar agar "sesuatu" bisa dikategorikan sebagai sebuah "jaringan", yaitu sebagai berikut:

1. Sekumpulan orang, objek, atau kejadian, minimal berjumlah tiga satuan yang berperan sebagai terminal (pemberhentian). Biasanya dipresentasikan dengan titik-titik, yang dalam peristilahan jaringan disebut sebagai aktor atau node (simpul).

2. Seperangkat ikatan yang menghubungkan satu titik ke titik yang lainnya dalam jaringan. Ikatan ini biasanya dipresentasikan dengan "garis" yang merupakan suatu saluran atau jalur. Berupa mata rantai atau rangkaian. Ikatan ini bisa dibedakan menjadi dua jenis, yaitu:

a) ikatan yang tampak dan

b). Ikatan yang tidak tampak.

Progress in Social Development: Volume 1 No 1 Januari 2020 
3 Arus, ada sesuatu yang "mengalir" dari satu titik ke titik lainnya, melalui saluran atau jalur yang menghubungkan masing-masing titik dalam jaringan

\subsection{Jaringan Sosial}

Lawang dalam Mudiarta mendefinisikan jaringan sosial terbentuk karena adanya rasa saling tahu, saling menginformasikan, saling mengingatkan, dan saling membantu dalam melaksanakan ataupun mengatasi sesuatu. Intinya, konsep jaringan dalam social capital menunjuk pada semua hubungan dengan orang atau kelompok lain yang memungkinkan kegiatan dapat berjalan secara efisien dan efektif. Lebih lanjut lagi jaringan sosial terbentuk berawal dari suatu interaksi sosial yang kemudian berlanjut membentuk hubungan sosial, lalu dari hubungan sosial yang berkualitas itu terbentuk suatu jaringan sosial yang merupakan suatu pengelompokan sosial. (Mudiarta,Hal.6)

Menurut Agusyanto ditinjau dari hubungan sosial yang membentuk jaringan- jaringan sosial yang ada dalam masyarakat, dapat dibedakan menjadi tiga jenis jaringan sosial, yaitu sebagai berikut :

1) Jaringan interest (kepentingan), dimana hubungan sosial yang membentuknya adalah hubungan sosial yang bermuatan kepentingan. 2) Jaringan sentiment (jaringan emosi), dimana jaringan yang terbentuk atas dasar hubungan sosial yang bermuatan emosi, seperti hubungan dalam pertemanan, percintaan atau hubungan kerabat dan sejenisnya. 3) Jaringan power (jaringan kekuasaan), dimana hubungan sosial yang terbentuk bermuatan kekuasaan. Pada jaringan power, konfigurasi-konfigurasi saling keterhubungan antar pelaku didalamnya disengaja atau diatur. Tipe jaringan sosial ini muncul bila pencapaian tujuan-tujuan yang telah ditargetkan membutuhkan tindakan kolektif dan konfigurasi saling keterhubungan antar pelaku biasanya dibuat permanen. Hubungan-hubungan power ini biasanya ditujukan pada penciptaan kondisi-kondisi yang dibutuhkan untuk mencapai tujuan-tujuan yang telah ditetapkan. (Agusyanto, R. Hal.34-38)

\subsection{Jaringan Sosial dalam Kapital Sosial}

Putnam dalam Dharmawan menjelaskan kapital sosial sebagai hal yang bersifat produktif untuk mencapai suatu tujuan (Dharmawan, Arya H. Hal.5). mendefinisikan kapital sosial berangkat dari pengertian bahwa suatu komunitas dapat bertahan dengan sebuah subtansi penting dari modal sosial, dimana modal ini mempunyai komponen penting yaitu keterlibatan aktif dalam pengembangan jaringan sosial, norma-norma yang sudah terinternalisasi dan kepercayaan sosial. Dengan kata lain, kapital sosial itu bersifatproduktif, memungkinkan pencapaian tujuan tertentu, yang tanpa kontribusinya tujuan itu tidak akan tercapai. Wujud struktur sosial yang menjadi satuan analisis studi Putnam ataupun pengikut aliran ini adalah institusi sosial (termasuk di dalamnya analisis kebutuhan pokok, cara-cara pemenuhan kebutuhannya baik dalam pengembangan perilaku maupun dalam bentuk organisasi).

Sedangkan Fukuyama lebih menekankan pada efektifitas kerjasama atas tim dengan kepercayaan tinggi (high trust). (Fukuyama. Hal.38). Kapital sosial memiliki konsekuensi-konsekuensi utama bagi penentuan hakikat ekonomi industri yang akan bisa diciptakan oleh masyarakat. Jika orang-orang yang bekerja bersama dalam sebuah perusahaan saling mempercayai dan bekerja menurut serangkaian norma-norma etis bersama, maka berbisnis hanya memerlukan sedikit biaya. Masyarakat demikian akan lebih mampu berinovasi secara organisasional, karena tingkat kepercayaan yang tinggi akan memungkinkan munculnya varietas hubungan sosial yang lebih luas

\subsection{Kekuatan Ikatan Jaringan}

Terkait informasi dalam konsep jaringan sosial yang di katakan oleh Lawang, Granovetter mengetengahkan konsep Kekuatan Ikatan Lemah (The Strength of Weak Ties).( Borgatti SP, dan Halgin On Hal.11). Ditemukan dalam satu studi bahwa kekuatan ikatan lemah lebih banyak dapat menjadi penting dalam mencari informasi dan inovasi, di bandingkan dengan teman-teman dekat aktor (kekuatan ikatan kuat) yang cenderung bergerak dalam lingkungan yang sama dan satu aktivitas, mereka memiliki informasi tumpang tindih dengan apa yang sudah aktor ketahui. Kenalan dan orang-orang yang baru dikenal lebih memberikan peluang kepada aktor untuk menerima informasi baru. Hal ini disebabkan kenalan biasanya kurang mirip/berbeda dengan aktor dibanding teman-teman dekat yang memiliki banyak kesamaan (misal: hobi dan pekerjaan) serta intensitas pertemuan yang lebih sedikit. Ikatan lemah menghubungkan aktor pada dunia/cakrawala yang lebih luas. Oleh karena itu, dapat dijadikan sumber daya yang baik, mengetahui hal yang belum diketahui oleh kelompok/teman dekat kita seperti dalam mencari pekerjaan baru atau mendapatkan layanan yang langka. Ini adalah salah satu aspek dari apa yang disebut "Kekuatan Ikatan Lemah". 


\section{METODE.}

Penelitian ini menggunakan metode deskriptif kualitatif, bertujuan untuk mendapatkan gambaran secara jelas, lengkap, rinci, dan mendalam terkait dengan objek yang diteliti dan memberi jawaban yang valid terkait dengan fenomena yang terjadi di lapangan

\subsection{Sumber dan Jenis Data}

Sumber data primer dalam penelitian ini diperoleh melalui observasi lapangan yang dilakukan dengan cara melibatkan diri dalam kegiatan edukasi dan investigasi. Wawancara dengan narasumber dilakukan secara purposive dalam bentuk dialog langsung juga melalui email. Pemilihan informan didasarkan pertimbangan atau kriteria tertentu dari peneliti yaitu pihak-pihak yang berkaitan dengan permasalahan penelitian. Informan yang dimaksud adalah aktor-aktor jaringan COP yaitu Manajer Area COP Kalimantan/kapten APE Crusader, kapten APE Defender, serta mantan staf COP. Sumber data sekunder diperoleh data-data yang telah ada, yaitu arsip-arsip kantor dalam bentuk foto-foto kegiatan dan struktur organisasi serta kliping berita yang berasal dari website COP dan website media online.

\subsection{Teknik Pengumpulan Data}

Teknik dan proses pengumpulan data dalam penelitian ini meliputi observasi partisipatif, wawancara mendalam, serta dokumentasi. Adapun proses pengumpulan data sebagai berikut:

1. Peneliti mengamati secara rinci situasi, kejadian atau peristiwa orang-orang dan perilaku objek penelitian dengan cara melibatkan diri dalam kegiatan edukasi dan investigasi. Dalam hal ini peneliti juga mengadakan pendekatan secara personal melalui kegiatan diluar jam kerja seperti makan bersama untuk meningkatkan hubungan kedekatan dan kemudahan dalam memperoleh informasi.

2. Peneliti mengadakan wawancara terhadap beberapa informan secara terpisah melalui email dan dialog langsung berdasarkan kemudahan akses. Materi wawancara adalah hasil temuan observasi di lapangan serta informasi- informasi yang dieroleh dari pemberitaan kegiatan dari website COP dan media online. Hasil wawancara tersebut berupa kutipan dari pernyataan informan tentang pengalaman, sikap, keyakinan, dan pandangan mereka tentang pemanfaatan jaringan sosial COP di Kalimantan.

3. Untuk dokumentasi, peneliti memperoleh dokumen-dokumen kegiatan COP dalam bentuk foto-foto dari kantor COP melalui informan serta kliping pemberitaan yang diperoleh dari website COP dan media online.

\subsection{Teknik Analisis Data}

Teknik analisis data menggunakan Metode Perbandingan Tetap (Constant Comparative Method) yaitu secara tetap membandingkan satu data dengan data yang lain, kemudian secara tetap membandingkan kategori dengan kategori lainnya, seperti yang dikemukakan Glaser dan Strauss dalam buku mereka, The Discovery of Grounded Research.12 Berikut adalah proses analisis datanya:

1. Reduksi data

Peneliti meringkas data yang ada di dalam catatan lapangan yang dikaitkan dengan pertanyaan penelitian sebagai identifikasi satuan-satuan.

2. Kategorisasi data

Peneliti memilah setiap data ke dalam bagian-bagian yang memiliki kesamaan sebagai sebuah kategori yang kemudian diberi nama atau label.

3. Sintesisasi

Peneliti mencari ikatan antara satu kategori dengan kategori lainnya yang kemudian ikatan tersebut diberi nama/label.

4. Keabsahan Data

Peneliti melakukan konfirmasi dalam bentuk wawancara kepada aktor yang terlibat atas hasil observasi lapangan kemudian peneliti mengecek validitas data yang disampaikan aktor tersebut dengan data lainnya yaitu kliping berita yang diperoleh dari website resmi COP dan website media online serta wawancara dengan pihak lain yang telibat. Hasil cek validitas tersebut kemudian dikonfirmasi ulang kepada aktor yang bersangkutan serta dihubungkan dengan perkembangan 
observasi lapangan. Demikian data diolah secara terus menerus hingga menjadi data jenuh atau hasil akhir yang ilmiah.

5. Menyimpulkan hasil dan memberi saran.

\section{HASIL DAN PEMBAHASAN}

Centre for Orangutan Protection (COP) adalah organisasi yang bergerak dibidang penyelamatan orangutan. Merupakan organisasi nirlaba atau Lembaga Swadaya Masyarakat (LSM), terpisah secara institusional dari pemerintah, mengelola serta mengontrol sendiri kegiatan-kegiatan yang ada di dalamnya, dan terdapat partisipasi relawan, maka dalam hal ini COP sebagai elemen masyarakat yang bergerak dalam bidang lingkungan hidup merupakan mitra pemerintah sekaligus sebagai kontrol sosial dalam pelaksanaan kebijakan pemerintah. COP berkantor pusat di World Trade Centre II, Jalan Jend. Sudirman Kav. 29-31, Daerah Khusus Ibukota Jakarta. Mempunyai kantor perwakilan di Yogyakarta dan Kalimantan. Kantor perwakilan untuk wilayah Kalimantan berada di Perumahan Talang Sari Regency, Jalan Kebon Agung, Lempake-Samarinda, Kalimantan Timur.

COP bekerja secara langsung melindungi orangutan dari kejahatan dan kekejaman. Dengan menyelidiki, mendokumentasikan, mengungkap, dan jika perlu berkonfrontasi langsung melawan para pelaku kejahatan dan kekejaman terhadap orangutan bersama dengan masyarakat Kalimantan. Dalam perkembangannya, COP melakukan operasi-operasi penyelamatan orangutan, penegakan hukum dan meringankan penderitaan orangutan di kebun binatang maupun pemeliharaan satwa ilegal juga melakukan kegiatan sosialisasi atau penyadaran kepada masyarakat melalui kegiatan edukasi seperti school visit atau sosialisasi ke sekolah-sekolah, village visit atau sosialisasi ke kampung-kampung, pameran, kampanye, aksi, talkshow, seminar, workshop, dan sebagainya. Seperti yangdilakukan di Samarinda, COP bersama para relawan yang tergabung dalam Orangufriends melakukan pendampingan di Kebun Raya Samarinda (KRUS). Mereka membuat enrichment atau pengkayaan kandang untuk orangutan dan intepreter atau penyadartahuan ke pengunjung kebun binatang KRUS.

Dengan keterbatasan jumlah SDM dibanding luasnya cakupan kerja di seluruh Kalimantan, COP memanfaatkan jaringan sosialnya untuk memenuhi kebutuhan dan berjalannya fungsi organisasi. Pemanfaatan jaringan sosial di Kalimantan meliputi pemanfaatan jaringan sosial untuk kegiatan investigasi dan pemanfaatan jaringan sosial untuk edukasi. Aktor dalam pemanfaatan jaringan sosial COP terdiri atas aktor pusat dan aktor lokal. Aktor pusat merupakan pendiri COP dan stafnya yang berada di kantor pusat berperan sebagai penentu regulasi dan pengatur kebijakan untuk unit-unit kerjanya. Sedangkan aktor lokal merupakan aktor yang berada di dalam unit-unit atau tim lapangan yaitu APE Crusader dan APE Defender di Kalimantan yang berperan sebagai pelaksana regulasi dan kebijakan aktor pusat. Peran aktor meliputi kewenangan dalam menetapkan regulasi atau aturan dan pembuat kebijakan untuk pemanfaatan jaringan sosial.

Hasil observasi lapangan dan wawancara yang dilakukan oleh peneliti, menunjukkan adanya aktor-aktor yang berperan penting dalam pemanfaatan jaringan sosial COP di Kalimantan. Mereka adalah Ramadhani, Fian Khairunnisa, Kertaningtyas dan Imam Arifin, merupakan orang-orang yang pernah bekerja maupun masih bekerja sebagai staf COP di Kalimantan. Melalui aktor-aktor inilah COP mendapatkan informasi dan bantuan dari jaringannya dalam memenuhi kebutuhannya di Kalimantan. Hubungan di antara aktor adalah rekan kerja yang saling membantu sesuai dengan tugas dan kapasitas masing-masing.

Secara umum peran aktor lokal dalam kegiatan investigasi adalah pelaksana kegiatan, dengan aktor pusat sebagai penentu regulasi serta pengambil kebijakan. Aktivitas investigasi di lapangan dari perencanaan, strategi lapangan hingga keputusan final atas kasus-kasus yang diungkap, terintegrasi dalam strategi rencana aksi yang diputuskan oleh aktor pusat untuk memudahkan kontrol dan arah kegiatan.

Alur kegiatan investigasi, secara umum diawali dari informasi kontak lokal atau masyarakat kepada tim, laporan diteruskan kepada pusat, dilanjutkan dengan perintah pusat kepada tim untuk melakukan investigasi atas informasi tersebut. Temuan tim dilapangan kembali dilaporkan ke pusat, berlanjut intruksi pusat kepada tim untuk penanganan kasus tersebut. Apabila kasus memerlukan bantuan pihak lain seperti BKSDA dan BOSF maka aktor pusat kembali memerintahkan tim untuk melakukan koordinasi-koordinasi atau aktor pusat langsung berhubungan dengan pihak-pihak terkait ketika diperlukan dalam kondisi daruratDari masa ke masa dalam pergantian para aktor pola ini tetap atau tidak berubah, menunjukkan adanya peran aktor pusat yang memberlakukan jaringan power untuk mempertahankan jaringan kepentingannya. Termasuk hubungan dengan kontak lokal, aktor pusat menganggarkan untuk terpenuhinya kebutuhan yang diperlukan kontak lokal dalam kegiatannya membantu COP.

Peran aktor lokal dalam kegiatan investigasi selain sebagai pelaksana kegiatan juga menciptakan hubungan sentiment dalam jaringan kepentingan. Aktor dituntut memahami kebutuhan kontak lokal selain pulsa dan uang untuk operasional, misalnya kebutuhan sembako dan obat untuk keluarga kontak lokal. Terciptanya hubungan sentiment antar aktor di lapangan akan memudahkan pergerakan, nilai material yang 
diberikan kepada kontak lokal tidak menajadi ukuran mereka dalam membantu COP. Beberapa aktor melakukan komunikasi persuasif untuk mempertahankan hubungan sentiment mereka dengan kontak lokal diluar aktifitas investigasi, seperti mengirim sms: “Apa kabar pak?”. Upaya aktor lokal dalam menciptakan dan memepertahankan hubungan sentiment dengan kontak lokal tidak termasuk regulasi pusat melainkan kebijakan aktor lokal.

Dalam kegiatan edukasi, aktor pusat berperan sebagai penentu regulasi, menempatkan edukasi sebagai bagian dari rencana aksi perlindungan dan penyelamatan orangutan. Edukasi bertujuan untuk merubah presepsi dan perilaku masyarakat terhadap orangutan meski dalam prakteknya para aktor di Kalimantan dominan menempatkan edukasi sebagai cover story investigasi, sehingga fungsi edukasi sebagai alat penyadaran ke masyarakat dalam mengubah persepsi dan perilaku masyarakat terabaikan. Edukasi sebagai cover story investigasi tidak efektif menggali informasi keberadaan orangutan dan perusakan habitatnya. Fakta ini dapat diukur dari jumlah temuan kasus, dari masa ke masa dalam pergantian aktor-aktor, terdapat dua temuan kasus yang diperoleh melalui kegiatan edukasi, masing-masing pada masa Fian dan Ramadhani. Berbeda dengan kegiatan investigasi, dalam kegiatan edukasi aktor lokal berperan menentukan pola edukasi dan menyusun regulasi di tingkat lokal. Dominasi peran aktor lokal dalam kegiatan edukasi berpotensi melahirkan perbedaan asumsi antar aktor pada kegiatan edukasi, sehingga pola dan hasil kegiatan nampak berbeda dari masa ke masa dalam pergantian aktor-aktor. Perbedaan asumsi dilihat dari kepentingan para aktor dalam melaksanakan kegiatan edukasi.

Pada masa aktor Fian, kegiatan edukasi banyak terhubung dengan masyarakat melalui workshopworkshop. Fian juga mampu menggalang massa untuk bergabung menjadi anggota Orangufriends juga melibatkan Orangufriends dan masyarakat dalam kegiatan dan aksi-aksi sebagai tindak lanjut dari kasuskasus orangutan. Sedangkan pada masa aktor Ramadhani, kegiatan edukasi ditempatkan sebagai pekerjaan kedua setelah investigasi. Kegiatan sangat bergantung pada kesediaan waktu staf. Ketika staf sibuk kegiatan edukasi tidak berjalan. Peralihan pola dari Fian ke Ramadhani menghasilkan jaringan yang tetap dan tidak berkembang dan menurunnya jumlah anggota aktif Orangufriends.

Pada masa aktor Kertaningtyas, Orangufriends tergabung dalam tim edukasi, dengan staf berperan sebagai supervisi. Kegiatan edukasi didesain untuk tidak bergantung pada kesibukan staf. Terdapat program per semester yang disusun oleh tim dan di share kepada pusat, staf di Kalimantan dan Orangfriends. Pada masa ini COP di Kalimantan banyak terhubung dengan organisasi/ komunitas dalam bentuk sinergi kegiatan sebagai bentuk upaya membangun hubungan sentiment dalam jaringan kepentingan. Kegiatan tak terbatas pada persoalan orangutan melainkan secara umum terkait masalah lingkungan seperti berbagi waktu tayang/jadwal siaran dengan KOPHI Kaltim dan komunitas lainnya dalam talkshow "Lestari Alamku” di RRI pro 1 Samarinda. Hal ini menghasilkan kedekatan antar aktor serta menumbuhkan nilai-nilai kepercayaan. Seperti peran KOPHI Kaltim dalam memfasilitasi pertemuan dengan BEM Unmul untuk aksi penggalangan dana dengan menjual stiker dan donasi dari masyarakat Samarinda. Kedekatan juga terjalin dengan organisasi lainnya seperti IMAPA Unmul yang membantu COP menfasilitasi diskusi lintas KPA se Samarinda "Save Orangutan". Eksistensi jaringan sosial yang telah terbentuk masih berlangsung ketika Kertaningtyas sudah tak lagi sebagai staf COP. Pada beberapa kegiatan COP bersama jaringan eksternalnya di Kalimantan, Kertaningtyas masih terlibat dalam proses komunikasi, seperti pada kegiatan bedah buku "Orangutan Tersayang” oleh BEM Kehutanan Silva Unmul dan Pemutaran Film Dokumenter tentang Teluk Balikpapan oleh IMAPA Unmul.

Pola penguatan jaringan internal untuk pelaksanaan kegiatan dan pemanfaatan jaringan ekstenal untuk pengembangan jaringan sosial dalam kegiatan edukasi ini efektif menghasilkan dukungan tenaga, informasi dan keuangan bagi COP. Pola ini juga efektif menghasilkan hubungan sentiment antar aktor dan high trust sehingga melahirkan dukungan masyarakat dalam bentuk tenaga, informasi dan keuangan bagi COP. Hal ini dapat menjadi tolak ukur tercapainya tujuan edukasi dalam mengubah presepsi dan perilaku masyarakat terhadap orangutan. Dukungan tenaga, penyusunan dan pelaksanaan program kerja dilakukan oleh Orangufriends dengan staf berperan sebagai pendamping sehingga meringankan pekerjaan staf. Dukungan informasi, tim bekerjasama dengan beberapa stasiun radio di Samarinda untuk talkshow secara rutin dalam acara bertemakan lingkungan hidup. Beberapa anggota KOPHI Kaltim juga membantu aktor memetakan lokasi dan informasi perburuan satwa liar di daerah Melak Kalimantan Timur. Dukungan keuangan, Orangufriends turut mendanai kegiatan edukasi serta adanya aksi beberapa komunitas/organisasi lokal di Kalimantan yang menggalang dana untuk upaya perlindungan orangutan yang hasilnya didonasikan kepada COP.

Pada masa Imam Arifin, kegiatan edukasi kembali dimanfaatkan untuk kepentingan investigasi. Beberapa school visit dilakukan di sekitar ring habitat merupakan follow up atas beberapa temuan kasus orangutan. Imam tidak optimal memanfaatkan jaringan dan program edukasi yang telah ada sebelumnya, melainkan membuka jaringan dan menyusun program baru untuk memenuhi kepentingannya. Peralihan pola dari Kertaningtyas ke Imam menghasilkan ketidakberlanjutan program aktor sebelumnya serta penurunan

Progress in Social Development: Volume 1 No 1 Januari 2020 
ketebalan arus antar simpul dan ikatan dalam jaringan edukasi. Penurunan ketebalan arus tampak dari melemahnya hubungan COP dengan KOPHI Kaltim. Asumsi yang berbeda antar aktor dalam program dan pelaksanaan kegiatan edukasi menyebabkan aktivitas ini tidak berkelanjutan. Kerusakan jaringan dalam bentuk melemahnya arus hubungan antar simpul dan ikatan dalam jaringan sosial yang telah terbentuk juga bisa terjadi ketika terdapat pergantian aktor dengan pola yang berbeda.

\section{KESIMPULAN}

Pemanfaatan jaringan sosial di Kalimantan untuk memenuhi kebutuhan COP meliputi pemanfaatan untuk kegiatan investigasi dan edukasi. Pemanfaatan dilakukan oleh para aktor, yaitu aktor pusat dan aktor lokal. Jaringan sosial COP terbentuk atas ikatan-ikatan kepentingan didalamnya. Pemanfaatan jaringan sosial untuk kegiatan investigasi, aktor pusat memberlakukan jaringan power untuk mempertahankan jaringan kepentingannya. Pusat mengontrol seluruh aktivitas unit-unit kerjanya di Kalimantan dalam jaringan internalnya, serta menjalin hubungan dan komunikasi secara langsung dengan jaringan eksternalnya. Pola ini menghasilkan keteraturan kerja dan terpenuhinya kebutuhan dan kepentingan antar aktor.

Dalam menggali informasi tentang keberadaan orangutan dan perusakan habitatnya, COP efektif memanfaatkan ikatan lemah. Tim COP di Kalimantan dengan cepat mencari informan-informan untuk mengawali penyelidikannya. Jaringan investigasi yang bersifat bonding atau tertutup menghasilkan informasi yang cepat dan rahasia sebelum dipublikasi sebagai isu publik melalui media massa. Jaringan sosial yang bersifat bonding merupakan tipe kapital sosial dengan karakteristik adanya ikatan yang kuat (adanya perekat sosial) dalam suatu sistem kemasyarakatan sehingga berpotensi menghasilkan hubungan sentiment antar aktor. Struktur sosial yang dibentuk oleh hubungan-hubungan emosi ini cenderung lebih mantap dan permanen serta menghasilkan suatu rasa solidaritas, artinya para pelaku cenderung mengurangi kepentingankepentingan pribadinya. Kepercayaan yang tinggi (high trust) lebih mudah terbentuk dalam jaringan ini.

Keterlibatan aktor pusat dalam jaringan powernya dalam menjamin terpenuhinya kebutuhan dan kepentingan antar aktor dan ikatan mendorong tumbuhnya rasa saling percaya (high trust) antar aktor juga keteraturan tindakan kolektif dan konfigurasi saling keterhubungan antar pelaku dalam jaringan sosial. Kompilasi hubungan sentiment antar aktor, high trust dan jaringan power menghasilkan stabilitas jaringan dari masa ke masa dalam pergantian aktor-aktor sehingga COP mampu menjadi organisasi yang eksis di bidang investigasi. Eksistensi ini dapat diukur dari besarnya dukungan publik dan penghargaan dunia yang diterima COP.

Sisi lainnya, sifat jaringan yang bersifat tertutup (bonding) menghasilkan keterbatasan hubungan COP dengan organisasi atau pihak lain yang berbeda jenis, seperti organisasi yang bergerak dibidang ekonomi, sosial, dan budaya. Aktivitas dan jaringan sosial COP terbatas pada upaya-upaya perlindungan dan penyelamatan orangutan khususnya tanpa memperhatikan elemen penting pendukung konservasi alam lainnya seperti kepentingan masyarakat di bidang ekonomi, sosial dan budaya. Ketika pihak lain seperti perusahaan kelapa sawit mampu memenuhi kebutuhan tersebut seperti ganti rugi atas lahan masyarakat dan kerjasama perusahaan kelapa sawit dengan pemerintah untuk pembagunan daerah setempat serta kerjasama kemitraan antara perusahaan kelapa sawit dan masyarakat, COP berpotensi mengalami kegagalan dalam mempertahankan habitat orangutan. Hal ini dapat dilihat dengan kasus-kasus hilangnya hutan habitat yang dipertahankan COP seperti hutan habitat di Tumbang Koling dan Muara Wahau. Pemanfaatan jaringan sosial untuk kegiatan edukasi, jaringan power tidak dominan bekerja melainkan kebijakan aktor lokal dalam menentukan program dan pelaksanaan kegiatan di lapangan. Tak ditemukan regulasi pusat yang mengatur program dan pola kegiatan edukasi di Kalimantan. Pusat dalam strateginya hanya mengatur edukasi sebagai bagian dari aksi perlindungan dan penyelamatan orangutan dengan merubah persepsi dan perilaku masyarakat terhadap orangutan. Pola ini menghasilkan perbedaan asumsi antar aktor sehingga pogram dan pola pelaksanaan kegiatan pun beragam. 


\section{DAFTAR PUSTAKA}

Agusyanto, R. 2007. Jaringan Sosial dalam Organisasi. Jakarta: Rajawali Pers. Fukuyama, 2002. Kebijakan sosial dan Penciptaan Kemakmuran. Terjemahan

The Sosial Vitues and The Creation of Prosperity, 1995. CV Qalam: Yogyakarta.

Moleong, L.J. 2009. Metodelogi Penelitian Kualitatif (Edisi Revisi). PT. Remaja Rosdakarya: Bandung.

Sugiyono, Dr. 2010. Metode penelitian Kuantitatif Kualitatif dan R\&D, Penerbit. Alfabeta: Bandung.

Whyte, Sean. 2011 APE Crusader. Halsgrove House: Wellingtoan, Soamerset

\section{Karya Ilmiah}

Assa'di, Husain. 2009. “Lembaga Swadaya Masyarakat (LSM) di Tengah Kepentingan Donor”. Sekolah Pascasarjana IPB Bogor.

Dharmawan, Arya H. 2002. "Kemiskinan Trust dan stok Modal Sosial Masyarakat Indonesia Baru". Makalah dibawakan dalam seminar dan kongres nasional V Ikatan Sosiologi Indonesia. Bogor. 27-29 Agustus 2002.

Febrina, Senorita. 2011. "Transaksi Pemenuhan Kebutuhan Antar Aktor di Jaringan Sosial Anggi yang Menyebabkan Anggi Foundation Tetap Eksis”. UI Jakarta.

Mudiarta, K.G. 2009. "Jaringan Sosial (Networks) dalam Pengembangan Sistem dan Usaha Agribisnis: Perspektif Teori dan Dinamika studi Kapital Sosial”. Badan Peneltian dan Pengembangan Pertanian:Jakarta.

\section{Ebook}

Borgatti. SP, dan Halgin. DS, 2011. On Network Theory.

Woolcock M, dan Narayan D. 2000. Social Capital: implication for Development Theory. Research, and Policy. The World Bank Research Observer. Vol. 15.No.2

\section{Sumber Internet}

BEM UNMUL, 2013. Galang Bantuan Dana untuk Bantu Pengelolaan OrangUtan Bersama COP (Centre for Orangutan Protection).

http://bemunmul.org/berita-174-galang-bantuan-dana-untuk-bantu-pengelolaan-orangutan-bersama-cop-center-for-orangutan-protection.html (Diakses 02

Mei 2013)

COP, 4 Februari 2013. Kerjasama Terpadu Perlindungan Orangutan (Pongo Pygmaeus Morio). http://orangutanprotection.com/indexina.php?menu=show_weblog.php\&id=252\&

lang=ina (Diakses 25 April 2013)

.14 Februari 2013. Biarkan Orangutan Tetap Liar.

http://orangutanprotection.com/indexina.php?menu=show_weblog.php\&id=255\&

lang=ina (Diakses 24 April 2013)

. 19 Juli 2013. Selamat Tinggal Hutan Tumbang Koling.

http://orangutanprotection.com/indexina.php?menu=shonnn8w_weblog.php\&id=

293\&lang=ina (Diakses 21 Agustus 2013)

. 10 September 2013. Dari Sabang Sampai Merauke.

http://orangutanprotection.com/indexina.php?menu=show_weblog.php\&id=304\&

lang=ina (Diakses 12 Oktober 2013)

Departemen Kehutanan, 2009. Siaran Pers Nomor: 98/PIK-1/2009 Departemen Kehutanan Gelar Lokakarya Implementasi Strategi dan Rencana Aksi Konservasi Orangutan di Indonesia. http://www1.dephut.go.id/idex.php/news/details/5323 (Diakses 24 April 2013) 
Kemenperin, 29 Januari 2007. Siaran Pers Kementrian Perindustrian Republik

Indonesia. http://www.kemenperin.go.id/artikel/494/Prospek-Dan-Permasalahan-Industri-Sawit/

(Diakses 27 April 2013)

Kompas, 4 Februari 2013. Jumlah Subspesies "Pongo Pygmaeus Morio" Paling Sedikit. http://sains.kompas.com/read/2013/02/04/23004012/Jumlah.Subspesies.Pong

o.Pygmaeus.Morio.Paling.Sedikit (Diakses 08 Oktober 2013)

Pro Fauna, 16 Juli 2013. Tentang Hutan Kalimantan. http://www.profauna.net/id/kampanye-hutan/hutankalimantan/tentang-hutan-

kalimantan\#.UlVqz909vJ4 (Diakses 08 Oktober 2013) 